\title{
Evaluation of blood glucose in type II diabetic patients submitted to local anesthesia with different vasoconstrictors
}

\author{
Avaliação da glicemia de pacientes diabéticos submetidos à anestesia local com diferentes vasoconstritores
}

\author{
Renan Pollettini de MELLO' \\ Juliana Cama RAMACCIATO' \\ Daiane Cristine PERUZZO' \\ Carllini Barroso VICENTINI² \\ Cristiane de Cássia BERGAMASCHI \\ Rogério Heládio Lopes MOTTA ${ }^{1}$
}

\section{ABSTRACT}

\section{Objective}

In the dental clinic, the use of local anesthetics containing vasoconstrictors in diabetic patients are still controversial raising some doubts. Thus, the objective of this randomized crossover clinical trial was to evaluate blood glucose, pulse oximetry and heart rate of type 2 diabetic patients when submitted to local anesthesia using prilocaine 3\% associated to felypressin 0,03U / $\mathrm{ml}(\mathrm{G} 1)$ and $2 \%$ lidocaine associated to epinephrine 1: $100,000(G 2)$

\section{Methods}

The sample consisted of 20 compensated type 2 diabetic patients (both genders) who were taking oral hypoglycemic drugs. The volunteers underwent two periodontal sessions (scaling) and one of the solutions tested was used in each visit. The cited parameters were evaluated at three different times: before the procedure (T1), 10 minutes after anesthesia (T2) and after 20 minutes (T3).

Results

Regarding the blood glucose levels, no statistically significant difference was found in different times between G1 and G2 (p>0.05). Similarly, regarding pulse oximetry and heart rate, no statistically significant differences were observed in intervals assessed between groups ( $p>0.05)$, presenting values within normal limits.

\section{Conclusion}

Considering the vasoconstrictors and the volume of anesthetic solution used, the results suggest that the evaluated vasoconstrictors do not alter significantly blood glucose, pulse oximetry and heart rate in compensated type 2 diabetic patients.

Indexing terms: Diabetes mellitus. Local anesthesia. Vasoconstrictors.

\section{RESUMO}

\section{Objetivo}

Na clínica odontológica, o uso de soluções anestésicas locais contendo vasoconstritores em pacientes diabéticos ainda sucita algumas dúvidas. Desta forma, o objetivo deste ensaio clínico cruzado e randomizado foi avaliar de forma comparativa a glicemia, oximetria de pulso e frequência cardíaca de pacientes portadores de diabetes tipo II quando submetidos à anestesia local com prilocaína 3\% com felipressina 0,03Ul/ml (G1) e lidocaína a 2\% com epinefrina 1:100.000 (G2).

\section{Métodos}

Foram selecionados 20 indivíduos diabéticos do tipo II, compensados, sem distinção de gênero, que faziam uso de hipoglicemiantes orais. Os voluntários foram submetidos a duas sessões de instrumentação periodontal, sendo administrada uma das soluções testadas em cada consulta. Os parâmetros citados foram avaliados em três momentos distintos: antes do procedimento (T1), 10 minutos após a anestesia (T2) e após 20 minutos (T3).

\section{Resultados}

Para os valores de glicemia não houve diferença estatisticamente significante nos diferentes tempos entre G1 e G2 ( $p>0,05)$. Da mesma forma, em relação à oximetria de pulso e frequência cardíaca, não foram observadas diferenças estatisticamente significativas nos intervalos avaliados entre os grupos $(p>0,05)$, com valores dentro da normalidade.

\section{Conclusão}

Considerando a concentração dos vasoconstritores e o volume das soluções anestésicas empregadas, os resultados sugerem que os vasoconstritores avaliados não alteram de forma significativa a glicemia, oximetria de pulso e frequência cardíca de adultos portadores de diabetes tipo II compensados.

Termos de indexação: Diabetes mellitus. Anestesia local. Vasoconstritores.

\footnotetext{
${ }^{1}$ Faculdade São Leopoldo Mandic, Curso de Odontologia, Programa de Pós-Graduação em Odontologia. Rua José Rocha Junqueira, 13, Swift, 13045755, Campinas, SP, Brasil. Correspondência para / Correspondence to: RHL MOTTA. E-mail: <rogerio.motta@slmandic.edu.br>.

${ }^{2}$ Instituto Tocantinense Presidente Antonio Carlos. Porto Nacional, TO, Brasil.

${ }^{3}$ Universidade de Sorocaba, Departamento de Ciências Farmacêuticas. Sorocaba, São Paulo, Brasil.
} 


\section{INTRODUCTION}

Diabetes mellitus, a world-wide increasing disease, is related to a heterogeneous group of metabolic disorders characterized by hyperglycemia resulting from either defects in secretion or insulin action or even both ${ }^{1-}$ 2. Currently it is estimated that there are over 10 million people with diabetes living in Brazil ${ }^{3}$.

Many of the patients who seek dental care present systemic diseases, including diabetes, which are often unknown and not controlled. For these risk patients, thorough anamneses are recommended in order to recognize their biological conditions and establish the clinical risks during the intervention ${ }^{4}$. Moreover, the most critical the patient's systemic condition, the more important is the effective anxiety and pain control ${ }^{5}$.

The successful use of local anesthesia is essential for good dental treatment as well as dentist and patient interaction in order to help anxious or dental phobic patients to achieve confidence ${ }^{6}$. When pain is unexpectedly caused, there may be significant physiological changes during the dental procedures ${ }^{7-8}$.

With the evolution of local anesthetic solutions, their efficacy and clinical safety have been improved ${ }^{9}$. Nevertheless, there is still the possibility of systemic complications due to accidental intravascular injection, anesthetic inadequate choice, anesthetic overdose of salt or vasoconstrictor, unwanted drug interactions and more rarely, methemoglobinemia ${ }^{10}$.

Within this context, in the dental clinic the use of anesthetics containing adrenergic vasoconstriction in diabetic patients is still controversial due to the possibility of blood glucose increase. Some authors ${ }^{11-12}$ endorse the use of local anesthetics with epinephrine in compensated diabetic patients, however, further studies are still needed in order to assure the clinical safety of vasoconstrictor adrenergic use for this group of patients ${ }^{13-14}$.

So far, the comparative studies of the effects of local anesthesia using prilocaine $3 \%$ associated to felypressin 0,03UI / $\mathrm{ml}(\mathrm{G} 1)$ and $2 \%$ lidocaine associated to epinephrine 1: 100,000 (G2) in diabetic patients is scarce. Thus, the aim of this study was to evaluate blood glucose, pulse oximetry and heart rate of type 2 compensated diabetic patients when local anesthetic solutions containing two different vasoconstrictors are used in nonsurgical periodontal procedures.

\section{METHODS}

This study was approved by the Ethics Committee in Research of São Leopoldo Mandic Dental School (CAAE 27461914.0.0000.5374) and prior to appointments, volunteers signed a free and informed consent (IC), agreeing to participate in the research. This crossover randomized study consisted of a sample of 20 type 2 diabetes mellitus compensated patients (male and female) indicated to regular periodontal treatment performed by mechanical instrumentation (scaling and root planning). The patients were treated in two clinical sessions: Group 1 (G1) received $3,6 \mathrm{~mL}$ of a prilocaine solution associated to $3 \%$ felypressin 0,03Ul / ml (Prilonest ${ }^{\circledR}$, Nova DFL) and at G2 received a 3,6 $\mathrm{ml}$ of lidocaine 2\% associated to epinephrine 1: 100,000 (Alphacaine $100^{\circledR}$, Nova DFL)

After the volunteers signed the consent form, a small sample of blood from the fingertip was taken and placed in the digital glucometer (OneTouch UltraMini ${ }^{\circledR}$, Johnson \& Johnson). The sample included only the patients who presented blood glucose levels and HbA1c demonstrating that diabetes was under control. They should also be under continuous oral hypoglycemic drugs treatment, medical supervision and no dose alterations. Blood pressure was measured using a digital sphygmomanometer (G-Tech ${ }^{\circledR}$, Accumed) and pulse oximetry and heart rate measured by pulse oximetry (OXP-10, Emai ${ }^{\circledast}$, Transmai $\left.{ }^{\circledR}\right)$. Exclusion criteria consisted of volunteers presenting blood pressure levels higher than $140 \times 90 \mathrm{mmHg}$ or a history of hypersensitivity to the anesthetic solutions used in the research ${ }^{15}$.

Previously to each of the periodontal instrumentation sessions the blood glucose was measured (baseline - T1) and the volunteers were instructed to rinse with $15 \mathrm{~mL}$ of a chlorhexidine gluconate solution $0.12 \%$, for a minute. After that, local anesthesia was given with one of the anesthetic solutions tested: $2 \%$ lidocaine associated to epinephrine $1: 100,000$ or $3 \%$ prilocaine associated to felypressin $0,03 \mathrm{Ul} / \mathrm{ml}$. The anesthetic solutions were randomly administered (www.randomization.com) by the same operator. After aspiration, the anesthetic solution was slowly performed according to the standardized anesthetic technique (infiltrative technique and submucosa) ${ }^{16}$. The clinical procedure was performed and its duration was timed and recorded. The second assessment of the blood glucose level was performed 10 minutes after anesthesia (T2) and the third after 20 minutes (T3). The data were tabulated and statistically analyzed by means of Friedman and Wilcoxon 
tests, with level of significance of 5\%. The statistical program used was Bioestat version 5.3 (Mamirauá Institute, Brazil).

\section{RESULTS}

Considering the values obtained for blood glucose, there was no statistically significant difference between the groups, regarding the evaluation period ( $p>0.05$ ). However, when comparing the periods statistically significant differences were observed ( $p$ $<0.05$ ) for T2 and T3 values for group 1, as can be shown in Table 1.
Regarding the results obtained for the oxygen saturation, there was no statistically significant difference in the groups concerning the evaluation period ( $p>0.05$ ). However, for the intervals (T1, T2 and T3) within each group, significant difference was observed $(p<0.05)$ for values in T3, as shown in Table 2.

For heart rate, there was no statistically significant difference between the groups regarding the evaluation period ( $p>0.05$ ). However, regarding the comparison between the periods statistically significant differences were observed $(p<0.05)$ for the T1 and T2 values for group 1 , as shown in Table 3.

Table 1. Mean values and standard deviation of blood glucose $(\mathrm{mg} / \mathrm{dL})$ in the groups and periods.

\begin{tabular}{cccccc}
\hline Groups & T1 & T2 & T3 & P values \\
\hline G1 & $147.65 \pm 40.18$ & $149.9 \pm 44.75$ & $137.85 \pm 35.86$ & ${ }^{*} 0.0425$ \\
G2 & $142.35 \pm 34.83$ & $144.1 \pm 35.06$ & $137.55 \pm 38.66$ & 0.0517 \\
\hline$P$ values & 0,3760 & 0,8813 & 0,9256 & \\
\hline
\end{tabular}

Note: * Statistically significant difference in the intragroup analysis (Friedman, $p<0.05$ ). No statistically significant difference in the intergroup analysis (Wilcoxon, $p \geq 0$. 05).

Table 2. Mean and standard deviation values of oxygen saturation (percentage) in groups and periods.

\begin{tabular}{ccccc}
\hline Groups & T1 & T2 & T3 & P values \\
\hline G1 & $97.50 \pm 0.76$ & $97.35 \pm 0.93$ & $97.55 \pm 0.76$ & 0.890 \\
G2 & $97.70 \pm 0.98$ & $97.50 \pm 0.88$ & $98.05 \pm 0.60$ & 0.100 \\
\hline$P$ values & 0.4216 & 0.7776 & ${ }^{*} 0.0367$ & \\
\hline
\end{tabular}

Note: No statistically significant difference in the intragroup analysis (Friedman, $p>0.05$ ).

*Statistically significant difference in the intergroup analysis (Wilcoxon, $p<0.05$ ).

Table 3. Mean values and standard deviation of heart rate (bpm) in groups and assessed periods.

\begin{tabular}{ccccc}
\hline Groups & T1 & T2 & T3 & P values \\
\hline G1 & $73.00 \pm 12.47$ & $77.90 \pm 12.63$ & $74.75 \pm 13.03$ & ${ }^{*}<0.05$ \\
G2 & $75.45 \pm 12.49$ & $77.35 \pm 11.56$ & $73.75 \pm 11.86$ & 0.5842 \\
\hline$P$ values & 0.4209 & 0.9108 & 0.3144
\end{tabular}

Note: * Statistically significant differences in intragroup analysis (Friedman, $p<0.05$ )

No statistically significant difference in the intergroup analysis (Wilcoxon, $p>0.05$ )

\section{DISCUSSION}

In Brazil, there has been an increasingly demand for dental care of patients with systemic diseases such as diabetes and its prevalence ${ }^{1,3}$. Thus, special care must be delivered to these patients providing them with problemoriented anamnesis, assessment of vital signs added to signs added to the most appropriate local anesthetic solution choice. The more critical the systemic condition of the patient, the more important the effective control of anxiety and pain becomes ${ }^{4}$. In this context, an effective and safe local anesthesia to patients with this profile plays a role of utmost importance ${ }^{11-12}$.

The use of adrenergic vasoconstrictor as epinephrine regarding local anesthesia in diabetic patients has been treated in the literature ${ }^{17-18}$ effect of epinephrine in cellular glycogen breakdown is observed, leading to hyperglycemia Moreover, few studies have compared the effects of epinephrine and felypressin in blood glucose in diabetic patients, leading to this research.

Regarding the results of this study, blood glucose levels remained within acceptable values for 
compensated diabetic patients ${ }^{1,18}$. Besides that there was no statistically significant difference in blood glucose levels of patients undergoing both treatments suggesting the clinical feasibility of epinephrine or felypressin administration for patients with this profile. The results of this study corroborate with Haji et al. ${ }^{14}$ and Khawaja et al. ${ }^{17}$ showing that the use of lidocaine associated to epinephrine does not present significant difference in the blood glucose alterations for compensated diabetic patients. In addition, Santos-Paul et al. ${ }^{18}$ conducted a study and demonstrated that epinephrine associated to lidocaine did not lead to hyperglycemia significant changes either in hemodynamics or in anxiety parameters in type 2 diabetic and coronary disease patients. Other studies have also observed the safe use of epinephrine as a vasoconstrictor in these patients. Tily \& Thomas $^{13}$ found that local anesthesia with epinephrine can be used in both healthy and diabetic patients provided that their medication to control the disease had been taken.

Andrade ${ }^{19}$ states that the possible complications occurring after the administration of local anesthetics with epinephrine concentrations and volumes typically used in Dentistry are much smaller than the ones often occurring in the medical clinic. Moreover, diabetic patients have shown increased tolerance to vasoconstrictive agents and may benefit from small amounts of anesthetic solutions with epinephrine at a concentration of 1: 200,000 as long as the minimum dose employed is compatible with both deep and long enough anesthesia duration 5,14,19.

This study highlights another important factor as to values observed of oximetry and heart rate, since both parameters showed no statistically significant differences between groups, considering that diabetic patients may also present hypertension ${ }^{1,3,12}$. The effect of epinephrine in $\beta$-adrenergic receptors could cause tachycardia and consequently elevated blood pressure levels. However, the results of this study were within the physiological oximetry and heart rate patterns, demonstrating the clinical safety of epinephrine when used in lower concentrations in type 2 compensated diabetic patients. Although minor changes in the evaluated intervals have been observed, felypressin has also proved to be a viable clinical option vasoconstrictor for type 2 diabetic patients. It is essential to observe epinephrine action on adrenergic receptors in the walls of arteries and veins causing intense vasoconstriction, while felypressin acts directly on the muscular layer of blood vessels, especially on the venous side ${ }^{20}$. Thus, in order to provide better hemostasis control epinephrine solutions would be recommended for major bleeding risk in surgical procedures ${ }^{19}$. The obtained results showed that both anesthetics caused no significant change in blood glucose, pulse oximetry and heart rate in compensated type II diabetic patients. However, further controlled clinical trials are suggested, considering the sample size of this study and the lack of research on the subject in the literature.

\section{CONCLUSION}

Considering the vasoconstrictors and the volume of anesthetic solution used, the results suggest that the evaluated vasoconstrictors do not alter significantly blood glucose, pulse oximetry and heart rate in compensated type 2 diabetic patients.

\section{Collaborators}

RP de MELLO, collect of data, literature review and writing of the manuscript. JC RAMACCIATO, writing and critical review of the manuscript. DC PERUZZO, collect of data and critical review of the manuscript. CB VICENTINI, collect of data and preparation of the manuscript. CC BERGAMASCHI, statistical analisys and preparation of the manuscript. RHL MOTTA, writing and critical review of the manuscript. 


\section{REFERENCES}

1. Sociedade Brasileira de Diabetes [online]. São Paulo: SBD; 2016 [citado 2016 abr 26]. Disponível em: <http://www.diabetes.org. br>.

2. American Diabetes Association. Diagnosis and classification of diabetes mellitus. Diabetes Care. 2010 Jan;33(Suppl 1):S62-9.

3. AC Farmacêutica. Diretrizes da Sociedade Brasileira de Diabetes (2015-2016). São Paulo: Gen; 2016.

4. Malamed SF. Knowing your patients. J Am Dent Assoc. 2010 May;141(Suppl 1):3S-7S. doi: 10.14219/jada.archive.2010.0350

5. Caldas CS, Bergamaschi CC, Succi GM, Motta RHL, Ramacciato JC. Clinical evaluation of different ephinephrine concentration for local dental anestesia. Rev Dor. 2015 jan-mar;16(1):1-5. doi: 10.5935/1806-0013.20150001

6. Palmer-Bouva C, Oosting J, deVries R, Abraham-Inpijn L. Stress in elective dental treatment: epinephrine, norepinephrine, the VAS, and CDAS in four different procedures. Gen Dent. 1998 JulAug;46(4):356-60.

7. Gortzak RA, Oosting J, Abraham-Inpijn L. Blood pressure response to routine restorative dental treatment with and without local anesthesia: continuos noninvasive blood pressure registration with a finger manometer. Oral Surg Oral Med Oral Pathol. 1992;73(6):677-81. doi: 10.1016/0030-4220(92)90008-E

8. Brand HS, Gortzak RA, Palmer-Bouva CC, Abraham RE, AbrahamInpijin L. Cardiovascular and neuroendocrine responses during acute stress induced by different types of dental treatment. Int Dent J. 1995 Feb;45(1):45-8.

9. Saxena P, Gupta SK, Newaskar V, Chandra A. Advances in dental local anesthesia techniques and devices: an update. Natl J Maxillofac Surg. 2013 Jan;4(1):19-24. doi: 10.4103/09755950.117873

10. Andrade ED. Ramacciato JC, Motta RHL. Interações medicamentosas adversas. In: Andrade ED. Terapêutica medicamentosa em Odontologia. 3a ed. São Paulo: Artes Médicas; 2014, p. 78-91.

11. Haas DA. An update on local anesthetics in dentistry. J Can Dent Assoc. 2002;68(9):546-51.
12. Tófoli GR, Motta RHL, Ramacciato JC, Andrade ED, Groppo FC, Ranali J, et al. Tratamento odontológico de pacientes com diabetes. Rev Assoc Paul Cir Dent. 2005;59(4):306-10.

13. Tily FE, Thomas S. Glycemic effect of administration of epinephrine-containing local anaesthesia in patients undergoing dental extraction, a comparison between healthy and diabetic patients. Int Dent J. 2007 Apr;57(2):77-83. doi: 10.1111/j.1875595X.2007.tb00442.x

14. Haji IU, Siddiq M, Rao S, Rai G, Hiregoudar JS, Pitale U. Study on blood glucose concentration in patients with diabetes undergoing dental extraction under local anesthesia with and without adrenaline. J Basic Clin Physiol Pharmacol. 2012;23(4):169-71. doi: 10.1515/jbcpp-2012-0023

15. Nobre F, Giorgi DM. Diagnóstico e classificação. Diretrizes Brasileiras de Hipertensão VI. Rev Hipertensão. 2010;13(1):12-19.

16. Malamed SF. Técnicas de anestesia maxilar. In: Malamed SF. Manual de anestesia local. $4^{\text {a }}$ ed. Rio de Janeiro: Guanabara Koogan; 2001.p. 144-71.

17. Khawaja NA, Khalil H, Parveen K, Alghamdi AM, Alzahrani RA Alherbi SM. An influence of adrenaline $(1: 80,000)$ containing local anesthesia (2\% Xylocaine) on glycemic level of patients undergoing tooth extraction in Riyadh. Saudi Pharm J. 2014 Dec;22(6):545-9. doi: 10.1016/j.jsps.2014.02.006

18. Santos-Paul MA, Neves IL, Neves RS, Ramires JA. Local anesthesia with epinephrine is safe and effective for oral surgery in patients with type 2 diabetes mellitus and coronary disease: a prospective randomized study. Clinics. 2015;70(3):185-9. doi: 10.6061/ clinics/2015(03)06

19. Andrade ED. Terapeutica medicamentosa em Odontologia. $3^{\mathrm{a}}$ ed ed. São Paulo: Artes Médicas; 2014

20. Cecanho R, De Luca Junior LA, Ranali J. Cardiovascular effects of felypressin. Anesth Prog. 2006;53(4):119-25. doi: 10.2344/0003-3006(2006)53[119:CEOF]2.0.CO;2

Received on: 3/6/2016

Final version resubmitted on: 22/8/2016

Approved on: 2/9/2016 